\title{
GAMBARAN FAKTOR RESIKO PASIEN DIABETES MELITUS TIPE II Di POLIKLINIK ENDOKRIN BAGIAN/SMF FK-UNSRAT RSU Prof. Dr. R.D KANDOU MANADO PERIODE MEI 2011 - OKTOBER 2011
}

\author{
${ }^{1}$ Nadyah Awad \\ ${ }^{2}$ Yuanita A.Langi \\ ${ }^{2}$ Karel Pandelaki
}

\author{
${ }^{1}$ Kandidat Skripsi Fakultas Kedokteran Universitas Sam Ratulangi Manado \\ ${ }^{2}$ Bagian Ilmu Penyakit Dalam Fakultas Kedokteran Universitas Sam Ratulangi Manado \\ Emailnadhya_alamri@yahoo.com
}

\begin{abstract}
Given the high prevalence in patients with type 2 diabetes where the incidence of 650.000 new cases each year. In type-2, the pancreas does not make enough insulin to keep blood sugar levels remain normal, often because the body does not respond well to insulin. Most people do not realize had been suffering from type 2 diabetes, although the situation has become very serious. Type 2 diabetes has become a commonly experienced in the world and in Indonesia, and the numbers continue to grow due to unhealthy lifestyles, obesity and lazy to exercise. Purpose: To determine how the image of risk factors in patients with type 2 diabetes in the clinic Endocrine and Metabolic Section / SMF FK-UNSRAT BLU RSU Prof. Dr. R.D. Manado Kandou the period of May-October2011. Methods: This type of research is a descriptive study using secondary data. Population of type 2 DM patients who come for treatment at the Polyclinic Endocrine and Metabolic Section / SMF FK-UNSRAT BLU RSU Prof.Dr. R.D. Kandou Manado the period of May - October 2011. The number of samples of 138 patients comprising 60 men and 78 women. Result: The case of DM Tiipe 2 in Endocrine and Metabolic Clinic ever found in women than in men. Acquired risk factors for type 2 diabetes mellitus is a BMI> 23 ever found in an obese BMI groups $1(25-29,9)$ of 37 patients, patients with stage 1 hypertension $(130-159 / 80-99 \mathrm{mmHg})$ obtained by 80 patients, patients with dyslipidaemia as many as 22 patients, patients with a family history of as many as 45 patients, patients with age $>40$ years as many as 130 patients, and patients who have risk factors for most of the patients with 3 risk factors as many as 74 patients. Conclusion: Risk factors affecting the incidence of type 2 diabetes mellitus in Endocrine and Metabolic Clinic is a BMI $>23$, hypertension $>140 / 90 \mathrm{mmHg}$, family history,age $>40$ years, dyslipidemia.
\end{abstract}

Key words : Risk factors, Diabetes mellitus type 2, Endocrine and Metabolic Clinic.

\begin{abstract}
Abstrak: Mengingat tingginya prevalensi untuk pasien dengan DM tipe 2 dimana insidennya sebesar 650.000 kasus baru tiap tahunnya. Pada tipe-2, pankreas tidak cukup membuat insulin untuk menjaga level gula darah tetap normal, seringkali disebabkan tubuh tidak merespon dengan baik terhadap insulin tersebut. Kebanyakan orang tidak menyadari telah menderita dibetes tipe 2, walaupun keadaannya sudah menjadi sangat serius. Diabetes tipe 2 sudah menjadi umum dialami didunia maupun di Indonesia, dan angkanya terus bertambah akibat gaya hidup yang tidak sehat, kegemukan dan malas berolahraga. Tujuan: Untuk mengetahui bagaimana gambaran faktor risiko pada pasien DM tipe 2 di Poliklinik Endokrin dan Metabolik Bagian/SMF FK-UNSRAT BLU RSU Prof. Dr. R.D. Kandou Manado periode Mei - Oktober 2011. Metode: Jenis penelitian merupakan penelitian deskriptif dengan menggunakan data sekunder. Populasi pasien DM tipe 2 yang datang berobat di Poliklinik Endokrin dan Metabolik Bagian/SMF FK-UNSRAT BLU RSU Prof.Dr. R.D. Kandou Manado periode Mei-Oktober 2011. Jumlah sampel 138 pasien yang terdiri dari 60 laki-laki dan 78 perempuan. Hasil: Kasus DM Tiipe 2 di Poliklinik Endokrin dan Metabolik terbanyak
\end{abstract}


didapatkan pada perempuan dibandingkan pada laki-laki. Faktor risiko yang didapatkan untuk terjadinya DM tipe 2 adalah IMT $>23$ terbanyak didapatkan pada IMT golongan obes 1 (2529,9) sebanyak 37 pasien, pasien dengan hipertensi stage 1 (130-159/80-99 $\mathrm{mmHg})$ didapatkan sebanyak 80 pasien, pasien dengan dislipidemia sebanyak 22 pasien, pasien dengan riwayat keluarga sebanyak 45 pasien, pasien dengan umur $>40$ tahun sebanyak 130 pasien, dan pasien yang memiliki faktor risiko paling banyak adalah pasien dengan tiga faktor risiko yaitu sebanyak 74 pasien. Simpulan: Faktor risiko yang berpengaruh terhadap kejadian DM tipe 2 di Poliklinik Endokrin dan Metabolik adalah IMT $>23$, hipertensi $>140 / 90 \mathrm{mmHg}$, riwayat keluarga, umur $>40$ tahun, dislipidemia.

Kata kunci : Faktor risiko, diabetes melitus tipe 2, Poliklinik Endokrin dan Metabolik.

World Health Organisation (WHO) mendefinisikan diabetes melitus (DM) sebagai penyakit yang ditandai dengan terjadinya hiperglikemia dan gangguan metabolisme karbohidrat, lemak, dan protein yang dihubungkan dengan kekurangan secara absolut atau relatif dari kerja dan atau sekresi insulin. ${ }^{1}$

Tahun 2003, WHO memperkirakan 194 juta atau 5,1\% dari 3,8 milyar penduduk dunia usia 20-79 tahun menderita DM dan diperkirakan pada tahun 2025 akan meningkat menjadi 333 juta. Di tahun yang sama International Diabetes Federation (IDF) menyebutkan bahwa prevalensi DM di dunia adalah $1,9 \%$ dan telah menjadikan DM sebagai penyebab kematian urutan ke tujuh di dunia. 1,2

Tingginya prevalensi DM, yang sebagian besar adalah tergolong dalam DM tipe-2 disebabkan oleh interaksi antara faktor-faktor kerentanan genetis dan paparan terhadap lingkungan. Faktor lingkungan yang diperkirakan dapat meningkatkan faktor risiko DM tipe-2 adalah perubahan gaya hidup seseorang, diantaranya adalah kebiasaan makan yang tidak seimbang akan menyebabkan obesitas. Selain pola makan yang tidak seimbang, aktifitas fisik juga merupakan faktor risiko dalam memicu terjadinya DM. Latihan fisik yang teratur dapat meningkatkan mutu pembuluh darah dan memperbaiki semua aspek metabolik, termasuk meningkatkan kepekaan insulin serta memperbaiki toleransi glukosa.

\section{METODE}

Penelitian ini merupakan penelitian deskriptif dengan menggunakan data se- kunder. Tempat penelitian ini dilaksanakan di Poliklinik Endokrin Bagian Ilmu Penyakit Dalam RSU Prof. Dr. R.D. Kandou Manado dan waktu penelitian dilaksanakan pada bulan November 2011-Januari 2012. Populasi yang di teliti adalah pasien Diabetes Melitus Tipe-2 yang datang berobat di Poliklinik Endokrin RSU Prof. Dr. R.D. Kandou Manado dan sampelnya yaitu pasien Diabetes Melitus Tipe-2 yang baru berobat selama periode waktu bulan Mei Oktober 2011.Data yang dikumpulkan berasal dari data sekunder rekam medik pasien mengenai faktor-faktor resiko terjadinya DM Tipe-2 dan diolah untuk selanjutnya dibuat presentase dan data tersebut disajikan dalam bentuk table distribusi frekuensi. Variabel penelitian yang akan diteliti adalah: Usia, Jenis kelamin, Hipertensi, Obesitas, Dislipidemia, Jumlah pasien DM Tipe-2, dan Riwayat keluarga.

Analisis kerja pada penelitian ini adalah: Mengumpulkan literatur-literatur berupa text book, jurnal dari perpustakaan dan internet sebagai landasan teori, mengumpulkan data pasien yang terdiagnosis DM Tipe-2 dari rekam medik di Poliklinik Endokrin dan Metabolik bagian Ilmu Penyakit Dalam RSU Prof.Dr. R.D. Kandou periode Mei-Oktober 2011, melakukan pendataan variabel-variabel yang akan diteliti, dan Data yang didapat kemudian diolah dan disusun dalam bentuk tabel distribusi frekuensi.

\section{HASIL}

Jumlah pasien yang berkunjung di poliklinik endokrin selama enam bulan 
terakhir adalah sebanyak 3.998 pasien. Namun dari 3.998 pasien tersebut didapatkan pasien baru yang menderita penyakit DM tipe-2 sebanyak 138 pasien yang terdiri dari 60 (43\%) laki-laki dan 78 (53\%) perempuan.

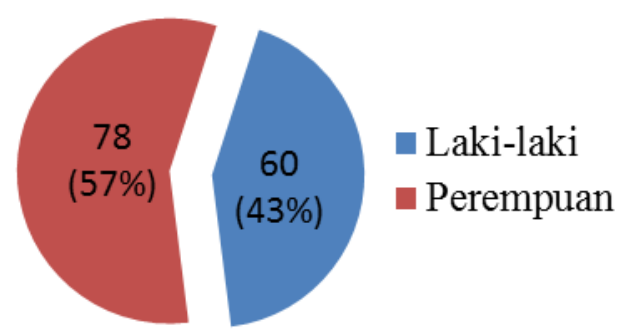

Gambar 1. Jumlah pasien baru berdasarkan jenis kelamin.

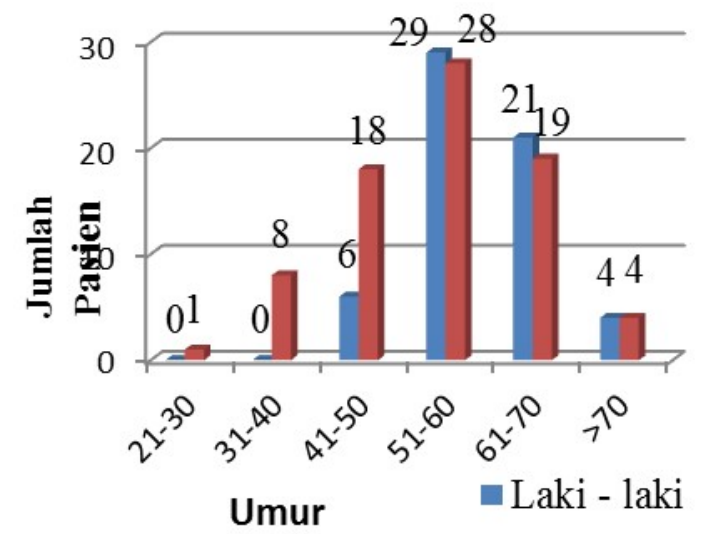

Gambar 2. Jumlah pasien baru berdasarkan kelompok umur.

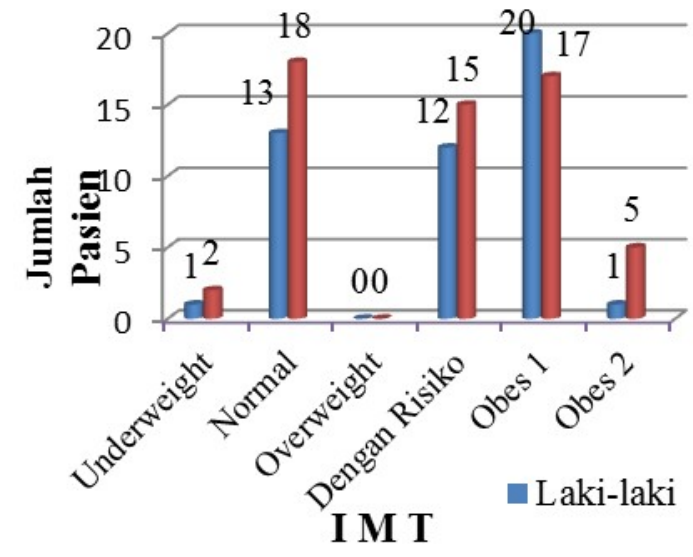

Gambar 3. Jumlah Pasien Berdasarkan Faktor Risiko IMT.

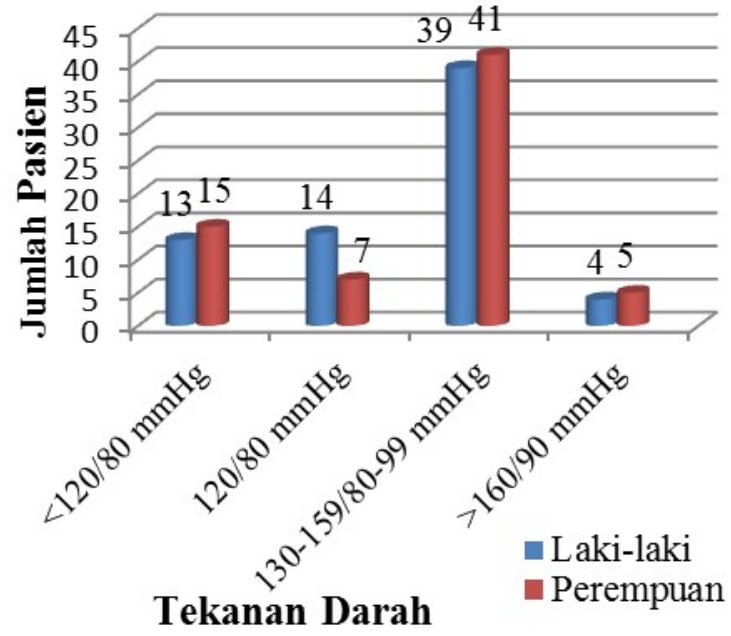

Gambar 4. Jumlah pasien berdasarkan faktor risiko hipertensi.

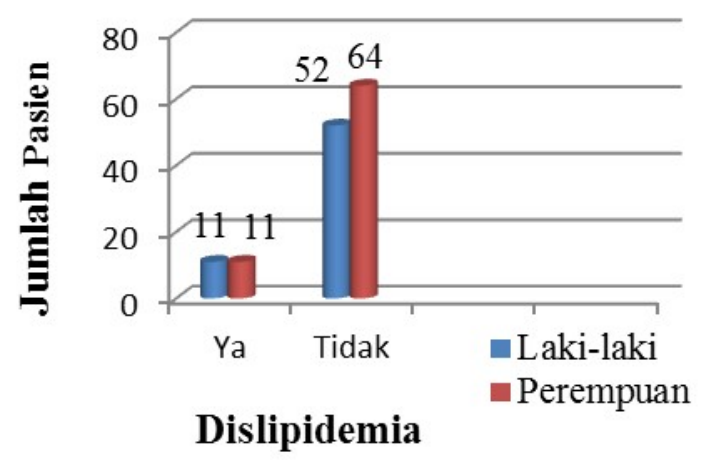

Gambar 5. Jumlah pasien berdasarkan faktor risiko dislipidemia.

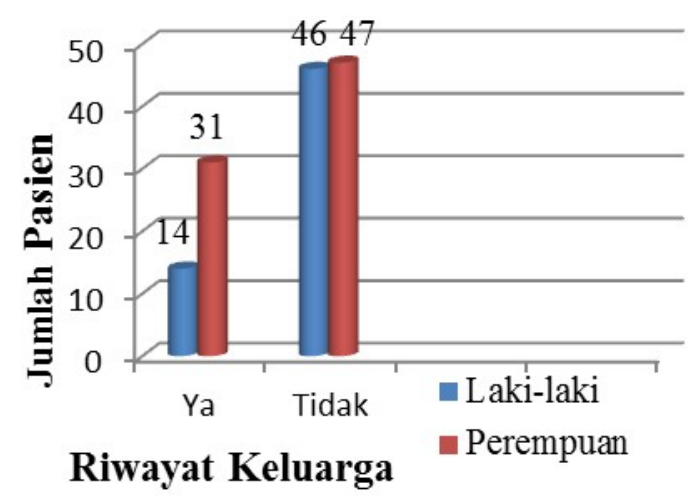

Gambar 6. Jumlah pasien berdasarkan faktor risiko riwayat keluarga. 


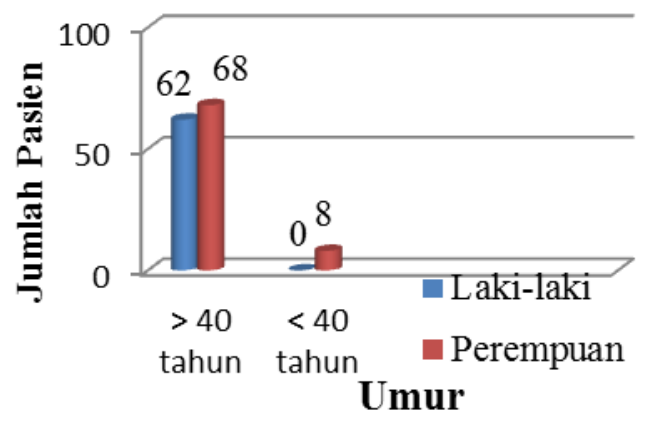

Gambar 7. Jumlah pasien berdasarkan faktor risiko menurut kelompok umur.

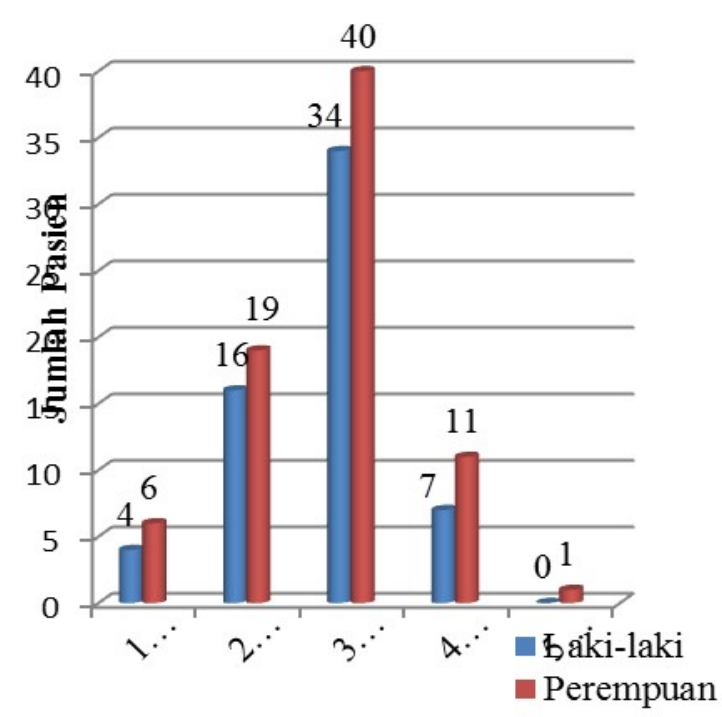

Gambar 8. Jumlah Pasien dengan Faktor Resiko

\section{BAHASAN}

Diabetes melitus umumnya meningkat seiring dengan bertambahnya usia. Hasil Riset Kesehatan Dasar (RISKESDAS) yang dilaporkan oleh Departemen Kesehatan pada tahun 2008, menunjukan prevalensi DM di Indonesia membesar sampai 5,7\%. ${ }^{3}$

Berdasarkan hasil penelitian ditemukan sebanyak 138 pasien DM tipe-2 di Poliklinik Endokrin RSU Prof.Dr.R.D. Kandou Manado. Dari 138 kasus tersebut, 78 pasien (57\%) adalah wanita dan 60 pasien $(43 \%)$ adalah pria. Umur terbanyak yaitu 51-60 tahun yaitu sebanyak 57 pasien (41,30\%). Hal ini sesuai dengan penelitian yang dilakukan di Kolombo, Sri Lanka terhadap pasien penderita DM tipe-2 bahwa pasien yang terbanyak menderita DM tipe2 yaitu pada wanita dibanding pria.

Pada penelitian ini, terdapat 104 pasien yang memiliki IMT sedangkan 34 pasien lainnya tidak memiliki IMT karena pada status pasien tersebut tidak dicantumkan BB dan TB pasien. Pada penelitian ini didapatkan faktor risiko menurut IMT pada pasien dengan resiko (23-24,9) sebanyak 27 pasien $(25,96 \%)$, pasien dengan obes- 1 $(25-29,9)$ sebanyak 37 pasien $(35,58 \%)$ dan pasien dengan obes-2 (>30\%) sebanyak enam pasien (5,77\%).Menurut CDC, di Amerika penyebab pasti penyakit ini belum diketa-hui, tetapi faktor gaya hidup seperti kelebihan berat badan atau tidak berolahraga sangat terkait dengan perkembangan diabetes tipe-2.

Jumlah pasien dengan faktor risiko hipertensi didapatkan pada hipertensi stadium-1 sebanyak 80 pasien $(57,1 \%)$ sedangkan pasien dengan hipertensi stage 2 didapatkan sembilan pasien (6,5\%). Menurut penelitian $40 \%$ pasien diabetes dengan tekanan darah lebih dari 160/90 $\mathrm{mmHg}$ dan $25 \%$ pasien dengan tekanan darah kurang dari 140/90 $\mathrm{mmHg}$.

Pada penelitian ini, pasien dengan dislipidemia sebanyak 22 pasien $(15,95 \%)$, sedangkan yang tidak ada dislipidemia sebanyak 116 pasien $(84,05 \%)$. Pada peneliti an yang dilakukan oleh Nakhjavani, dkk (2006) di Tehran, Iran bahwa dari 350 sampel pasien DM tipe-2 yang berusia 1982 tahun didapatkan bahwa perempuan lebih banyak menderita dislipidemia dibanding laki-laki. ${ }^{4}$

Pada penelitian ini didapatkan pasien yang mempunyai riwayat keluarga sebanyak 45 pasien $(32,61 \%)$ sedangkan yang tidak mempunyai riwayat keluarga sebanyak 93 pasien (67,39\%). Seperti penelitian yang dilakukan di Durango, Meksiko dari 189 pasien didapatkan 94 pasien $(49,7 \%)$ mempunyai riwayat keluarga DM tipe- $2 .{ }^{5}$

Pada penelitian ini didapatkan bahwa pasien yang sudah mempunyai usia lebih dari 40 tahun sebanyak 130 pasien $(94,2 \%)$ sedangkan pasien yang berusia kurang dari 40 tahun hanya delapan pasien $(5,8 \%)$. 
Penelitian yang dilakukan di Indonesia DM sangat jarang dijumpai di umur muda. Umumnya paling banyak didapatkan pada umur 40-60 tahun. ${ }^{6,7}$

Dari 138 kasus, pada penelitian ini didapatkan bahwa pasien memiliki beberapa faktor risiko untuk menderita diabetes. Adapun dari hasil yang ditemukan bahwa pasien yang memiliki faktor resiko paling banyak adalah pasien dengan tiga faktor risiko yaitu sebanyak 74 pasien $(53,62 \%)$, sedangkan pasien yang paling sedikit dengan lima faktor risiko hanya satu pasien $(0,75 \%)$. Di Indonesia, sekitar $95 \%$ kasus DM adalah DM Tipe-2, yang cenderung disebabkan oleh faktor gaya hidup yang tidak sehat. ${ }^{7}$

\section{SIMPULAN}

Pada penelitian ini ditemukan bahwa jumlah pasien lebih banyak wanita daripada pria, dan usia terbanyak yaitu umur 51-60 tahun baik pada wanita maupun pada pria.

Pada penelitian ini didapatkan faktor risiko menurut IMT pada pasien dengan resiko (23-24,9) sebanyak 27 pasien, pasien dengan obes-1 (25-29,9) sebanyak 37 pasien dan pasien dengan obes-2 (>30) sebanyak enam pasien.

Jumlah pasien dengan faktor risiko hipertensi didapatkan pada hipertensi stadium-1 sebanyak 80 pasien sedangkan pasien dengan hipertensi stadium-2 didapatkan sembilan pasien.

Jumlah pasien dengan faktor risiko dislipidemia didapatkan sebanyak 22 pasien.

Jumlah pasien dengan faktor risiko riwayat keluarga didapatkan sebanyak 45 pasien.

Jumlah pasien dengan faktor risiko umur lebih dari 40 tahun didapatkan sebanyak 130 pasien.

Jumlah pasien yang lebih dari satu faktor risiko didapatkan pada pasien yang memiliki tiga faktor resiko yaitu sebanyak 74 pasien.

\section{SARAN}

Penyakit Diabetes Melitus merupakan penyakit yang tidak bisa disembuhkan, tetapi dapat dicegah dengan pola hidup yang sehat.

Penekanan kasus Diabetes Melitus pada masyarakat dengan melakukan gaya hidup yang sehat guna menormalkan kadar glukosa darah sehingga terhindar dari penyakit DM.

Pada data pasien agar dapat dicantumkan TB $\left(\mathrm{m}^{2}\right)$ dan BB $(\mathrm{kg})$ pasien untuk bisa diketahui jika adanya faktor resiko obesitas pada pasien diabetes khususnya DM tipe-2.

\section{DAFTAR PUSTAKA}

1. Suyono S, Sudoyo A, Setiyohadi B, Alwi I, Setiati S, Simadibrat M, et al. Diabetes Melitus Indonesia. Jakarta: IPD FKUI; 2007. Hal.1852-7.

2. American Medical Assisiation. Guide for living with diabetes preventing and treating type 2 diabates. Esential information you and your family need to know. America: John Wiley and Sons, Inc, 2009; p.21-30.

3. Panduan Pengelolaan dan Pencegahan Pradiabetes di Indonesia. Jakarta: Penerbit PB. Persadia, 2009; hal.1.

4. Esteghamati RA, Esfahanian F. Dyslipidemia In Type 2 Diabetes Melittus: More Atherogenic Lipid Profile In Women [Serial online]. Year [cited 2006 Jul 2]. Available from: URL: http://journals.tums.ac.ir/upload_files/pdf/_ /2678.pdf.

5. Moran RM. Hyperinsulinemia and abdominal obesity are more prevalent in non-diabetic subjects with family history of type 2 diabetes. Arcmedres. [serial online]. 2000 [cited 2000 Mar 3]. Available from: http://www.arcmedres.com/article/S01884409\%2800\%2900089-8/abstract.

6. Noer. Gambaran Klinis Diabetes Melitus. Dalam: Sarwono W, editor. Buku Ajar Ilmu Penyakit Dalam. Edisi III. Jakarta: FKUI; 1996. P: 590

7. Supartondo. Diabetes Melitus: Terapi dengan Pendekatan Rasional. Dalam: Sarwono W, editor. Buku Rampai Ilmu Penyakit Dalam. Jakarta: FKUI, 1996; hal.165-6. 